УДК $615.322+577.121$

\title{
ХИМИЧЕСКИЙ СОСТАВ И БИОЛОГИЧЕСКОЕ ДЕЙСТВИЕ ЭКСТРАКТА Из ПЛОДОВ РЯБИНЫ
}

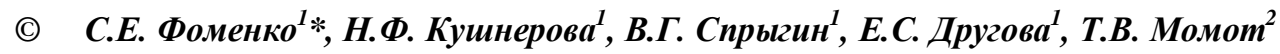 \\ ${ }^{1}$ Тихоокеанский океанологический институт им. В.И. Ильичева ДВО РАН, \\ ул. Балтийская, 43, Владивосток, 690041 (Россия), \\ e-mail: sfomenko@poi.dvo.ru. \\ ${ }^{2}$ Школа биомедицины Дальневосточного федерального университета, \\ ул. Суханова, 8, Владивосток, 690950 (Россия)
}

\begin{abstract}
Объектом настоящего исследования явился экстракт, полученный из высушенного жома рябины амурской (Sorbus amurensis Koehne) после отделения сока. Изучалось содержание общих полифенолов, липидный состав и анти-

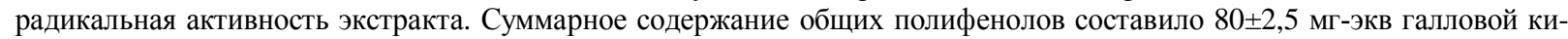
слоты/100 мл экстракта, что обусловливает высокий уровень его антирадикальной активности, который составлял $29,73 \pm 0,23$ ммоль-экв тролокса/л. Липидная часть экстракта включала 3 фосфолипидных фракции и 6 фракций ней-

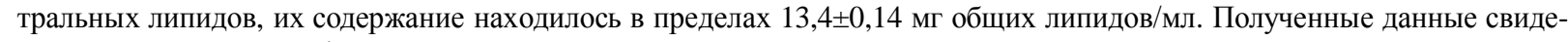
тельствуют о высокой биологической активности экстракта и перспективности проведения экспериментальных исследований. На модели токсического гепатита крыс, вызванного введением четыреххлористого углерода, показано, что экстракт из рябины амурской при внутрижелудочном введении в дозе 100 мг общих полифенолов на кг массы, обладает выраженным антиоксидантным и гепатопротекторным действием. Введение экстракта способствует снижению содержания общих липидов, удельной массы печени и активности аланинаминотрансферазы, также нормализуется уровень восстановленного глутатиона и активность антиоксидантных и лизосомальных ферментов. Экстракт из плодов рябины является перспективным источником для создания биологически активных добавок с высокой антиоксидантной и антирадикальной активностью.
\end{abstract}

Ключевые слова: экстракт плодов рябины, общие полифенолы, липиды, антирадикальная и антиоксидантная активность, токсический гепатит.

Работа поддержана Министерством образования и науки РФ, проект № 1326.

\section{Введение}

Рябина амурская (Sorbus amurensis Koehne), синоним рябина обыкновенная (Sorbus aucuparia L), относится к семейству Rosaceae - дерево высотой 4-6 м, реже кустарник. Плоды сочные с мелкими округлыми семенами, ярко оранжево-красные, сладко-горьковатые и терпкие на вкус, созревают в сентябре - октябре [1]. Декоративна во время цветения и созревания плодов. Естественно произрастает в Северо-Восточной Азии, южной части Дальнего Востока, Северной Маньчжурии, в Приморье, в южных и восточных районах При-

Фоменко Светлана Евгеньевна - ведущий научный сотрудник лаборатории биохимии, кандидат биологических наук, e-mail: sfomenko@poi.dvo.ru. Кушнерова Наталья Федоровна - заведующая лабораторией биохимии, доктор биологических наук, профессор

Спрыгин Владимир Геннадьевич - ведущий научный сотрудник лаборатории биохимии, кандидат биологических наук

Другова Елена Сергеевна - младший научный сотрудник лаборатории биохимии, кандидат биологических наук Момот Татьяна Викторовна - кандидат медицинских наук, доцент кафедры фундаментальной медицины амурья. Ягоды рябины издавна используются в народной медицине как в свежем, так и в сушеном виде. Из сухих плодов готовят отвары и применяют в качестве улучшающего аппетит, витаминного, легкого слабительного и диуретического средства. Плоды, соцветия и листья используют в производстве растительных продуктов и пищевых добавок.

Плоды рябины обыкновенной включены в Государственную фармакопею XI изд. как поливитаминное средство [2]. В плодах рябины обыкновенной содержатся органические кислоты, сахара,

\footnotetext{
* Автор, с которым следует вести переписку.
} 
каротины, аскорбиновая кислота, фенольные соединения, липиды, микроэлементы и др. [1]. По содержанию аскорбиновой кислоты ягоды рябины уступают лишь плодам шиповника и черной смородины [3]. Особый интерес представляют фенольные соединения, с которыми, как известно, связывают основные антиоксидантные свойства растительного сырья. Эти компоненты, являясь вторичными метаболитами растений, эволюционно адаптированы к употреблению человеком в пищу. Применение растительных полифенольных антиоксидантов, способных инактивировать свободные радикалы, имеет целый ряд положительных эффектов на здоровье человека. Ранее нами было установлено, что суммарный полифенольный комплекс, выделенный из жома ягод калины Саржента и винограда амурского, обладает выраженной антиоксидантной и антирадикальной активностью, проявляет гепатопротекторные свойства [4].

Важно отметить, что из всего многообразия растительного сырья (растения, фрукты, овощи, злаки, семена, кора и др.) только $10 \%$ исследуемых растительных источников достаточно обогащены полифенолами и могут быть использованы в качестве эффективных натуральных антиоксидантов [5]. Среди них несколько видов Sorbus, в том числе S. aucuparia, антиоксидантная активность которой описывается как сопоставимая или даже выше многих ценных ягод, таких как арония, черника, водяника. Это может быть обусловлено значительными различиями в фенольном составе рябины по сравнению с другими ягодами. Так, в экстракте плодов S. aucuparia по содержанию полифенолов главными составляющими являются хлорогеновая и неохлорогеновая кислоты (56-80\% от общих полифенолов) [6], концентрация которых почти эквивалентна количеству, представленному в кофейных зернах [7]. Помимо фенольных кислот, в экстракте присутствуют флавоноиды (гиперозид, кемпферол, кверцетин и их гликозиды), а также конденсированные проантоцианидины и антоцианы [5]. Таким образом, плоды рябины являются богатым источником фенольных соединений, имеющих высокий антиоксидантный потенциал и при этом безопасны для организма. Большинство полифенольных компонентов от различных растительных источников имеют низкую токсичность по сравнению с синтетическими антиоксидантами, повсеместно используемыми в производстве продуктов питания [8]. Это свидетельствует о перспективности создания на их основе растительных препаратов и биологически активных добавок с высокой антиоксидантной активностью. Кроме того, использование отходов от переработки ягодного сырья на пищевых производствах, в частности жом после отделения сока, который в настоящее время не утилизируется и не используется, является экономически выгодным.

Большинство работ по изучению химического состава рябины посвящено антиоксидантным компонентам, в частности полифенолам, и практически отсутствуют сведения о липидной составляющей экстрактивных извлечений из плодов, а также их фракционном составе. Имеются лишь единичные сообщения по этому вопросу, в частности, о наличии в семенах рябины до 22\% жирных масел [9]. Известно, что липидные компоненты также представляют биологически активные соединения, обладающие репаративным эффектом в отношении клеточных мембран.

Цель настоящей работы - исследование химического состава экстракта, полученного из высушенного жома рябины амурской (Sorbus amurensis Koehne), и его биологического действия на модели токсического гепатита у крыс.

\section{Экспериментальная часть}

Плоды рябины были собраны в период созревания (сентябрь 2013 г.) на экспериментальном участке Ботанического сада Дальневосточного отделения Российской академии наук. Для отделения сока и получения жома в лабораторных условиях свежесобранные плоды рябины помещали в специальный аппарат - винтовой пресс из легированной стали СВР-01. После прессования и отделения сока жом высушивали воздушным способом до содержания влаги не более $14 \%$ и измельчали до размеров частиц, равных $0,1-0,5$ см. Экстракцию сухого жома проводили 40\%-ным этиловым спиртом методом реперколяции, при этом выход экстракта составлял 1 л из 1 кг сырья. Экстракт упаривали в вакуумном испарителе до постоянного веса при температуре, не превышающей $40{ }^{\circ} \mathrm{C}$, затем разводили дистиллированной водой до необходимого объема.

Суммарное содержание общих полифенолов (ПФ) в экстракте определяли колориметрическим методом с помощью реактива Folin-Ciocalteu [10], используя в качестве стандарта галловую кислоту (ГК). Уровень антирадикальной активности оценивали по способности экстракта восстанавливать органический катион-радикал $\mathrm{ABTS}^{+}[11]$ и количественно выражали в эквивалентах тролокса - водорастворимого аналога витамина Е.

Липидную составляющую экстракта выделяли по методу J. Folch с соавт. [12]. Количество общих липидов в липидном экстракте определяли весовым способом в мг на 1 мл. Фракционное разделение фосфолипидов осуществляли методом двумерной микротонкослойной хроматографии на силикагеле [13], а их количественное определение - по методу [14]. Использовали следующие системы растворителей: в первом на- 
правлении - хлороформ : метанол : аммиак (28\%-ный) (65:25: 5 или $65: 35: 5$, по объему), во втором - хлороформ : ацетон : метанол : ледяная уксусная кислота : вода $(30: 40: 10: 10: 5$ или $50: 20: 10: 10: 5$, по объему). Хроматографическое распределение нейтральных липидов и их количественное определение проводили методом одномерной микротонкослойной хроматографии на силикагеле в системе растворителей гексан : серный эфир : уксусная кислота в соотношении $90: 10: 1$ (по объему) [15]. Обнаружение пятен нейтральных липидов осуществляли в камере с помощью паров йода. Количественное содержание отдельных фракций выражали в процентах от общей суммы нейтральных липидов и фосфолипидов соответственно.

Фармакологические исследования проводили на белых крысах-самцах линии Вистар массой 200220 г, содержащихся в стандартных условиях вивария при естественном освещении и постоянной температуре $20-22{ }^{\circ} \mathrm{C}$. Токсический гепатит у крыс моделировали с помощью четыреххлористого углерода $\left(\mathrm{CCl}_{4}\right)$, согласно руководству для проведения доклинических испытаний [16]: крысам внутрижелудочно через зонд вводили 50\%-ный масляный раствор $\mathrm{CCl}_{4}$ из расчета 1,25 мл/кг в течение 4 суток. Контрольным животным вводили оливковое масло в сопоставимой дозе. В качестве эталонного препарата сравнения использовали «Легалон ${ }^{\circledR} 140 »($ MADAUS AG, Германия). Лекарственная форма - капсулы (1 капсула Легалон-140 содержит 173-188,7 мг сухого экстракта из плодов расторопши пятнистой (Silybum marianum), эквивалентно 140 мг силимарина).

Водный раствор экстракта из жома рябины животным вводили внутрижелудочно через зонд в дозе 100 мг общих полифенолов на 1 кг массы животного в соответствии с рекомендациями А.И. Венгеровского и др. [17]. Полученный экстракт предварительно освобождали от спирта, затем доводили дистиллированной водой до концентрации 100 мг общих полифенолов в 2 мл раствора. Разведение проводили таким образом, чтобы терапевтическая доза, принятая в данном исследовании, а именно 20-22 мг общих полифенолов на одно животное, соответствовало 0,4 мл полученного разведенного препарата. Это количество вводили крысам один раз в день. Легалон вводили в виде взвеси в 1\%-ном крахмальном клейстере в той же дозе. В ходе эксперимента были выделены следующие группы животных по 10 крыс в каждой: 1 - контроль; 2 - внутрижелудочное введение $\mathrm{CCI}_{4}$ в течение 4 дней; 3 - введение $\mathrm{CCI}_{4}$ в течение 4 дней с последующей отменой (депривация) в течение 7 дней; 4 - ведение экстракта из жома рябины в период депривации в течение 7 дней; 5 - введение легалона в период депривации в течение 7 дней. Крыс выводили из эксперимента декапитацией под легким эфирным наркозом с соблюдением Правил и международных рекомендаций Европейской конвенции по защите позвоночных животных, используемых для экспериментов или в иных научных целях (Страсбург, 1986). Исследование одобрено Комиссией по вопросам этики Тихоокеанского океанологического института им. В.И. Ильичева ДВО РАН.

Кровь для исследований собирали из шейной вены животных в вакуэты с 1\%-ным раствором гепарина. Печень после извлечения промывали в физиологическом растворе, высушивали на фильтровальной бумаге, взвешивали и далее использовали для исследования биохимических параметров. Экстракты общих липидов из ткани печени готовили по методу J. Folch et al. [12]. Состояние антиоксидантной системы крови и печени оценивали по величине антирадикальной активности [11], активности супероксиддисмутазы [18], уровня восстановленного глутатиона [19] и малонового диальдегида [20]. Определение активности аланинаминотрансферазы в крови крыс проводили с помощью наборов Sigma Diagnostics (USA), активности $\beta$-глюкозидазы и $\beta$-галактозидазы ткани печени по методу [21]. Полученные данные обрабатывали с помощью параметрического критерия Стьюдента $(t)$, используя статистическую программу Instat (Graph Pad Software Inc. USA, 2005) со встроенной процедурой проверки соответствия выборки закону нормального распределения. Для определения статистической значимости различий в зависимости от параметров распределения использовали параметрический t-критерий Стьюдента или непараметрический U-критерий Манна-Уитни. Различия считали статистически значимыми при $\mathrm{p}<0,05$.

\section{Обсуждение результатов}

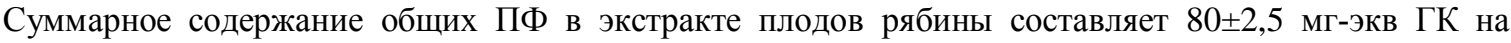
100 мл, его значения сопоставимы с представленными в литературе данными [6]. Значительное содержание общих ПФ в экстракте обусловливает высокий уровень антирадикальной активности (АРА), который составляет 29,73 $\pm 0,23$ ммоль-экв тролокса/л (табл. 1). Полученные данные подтверждают установленный факт, что антирадикальная активность экстракта плодов рябины коррелирует с содержанием полифенольных соединений [5].

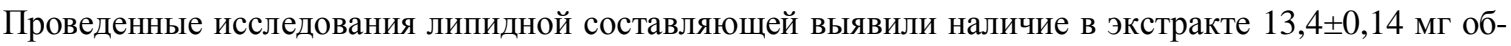
щих липидов/мл, в составе которых обнаружено 3 фосфолипидных фракции и 6 фракций нейтральных ли- 
пидов (табл. 1). Содержание идентифицированных фосфолипидов (фосфатидилхолин, фосфатидилэтаноламин и фосфатидилсерин) составляло в среднем 30-35\% от их общего количества. Среди нейтральных липидов обнаружены диацилглицерины (ДАГ), триацилглицерины (ТАГ), свободные жирные кислоты, эфиры жирных кислот, холестерин (ХС), эфиры холестерина (ЭХС). В процентном отношении преобладали ТАГ, ЭЖК и ЭХС, их содержание было в пределах 20-30\% от общего количества нейтральных липидов. Диацилглицерины и холестерин характеризовались как минорные фракции, их количество составляло в среднем 5-8\% от общей суммы нейтральных липидов.

Согласно нашим исследованиям, экстракт обладает низкой токсичностью $\left(\mathrm{LD}_{50}=56\right.$ мл/кг) и не оказывает вредного действия при длительных введениях в желудок и парентерально. Принимая во внимание суммарное содержание общих ПФ, высокий уровень их антирадикальной активности, а также наличие липидных компонентов, можно предполагать о высокой биологической эффективности экстракта и перспективности проведения экспериментальных исследований.

Введение $\mathrm{CCl}_{4}$ в течение четырех дней вызвало у животных типичную картину токсического гепатита с изменением весовых и биохимических показателей. Так, у животных отмечалось снижение массы тела на $17 \%$ ( $<<0,001)$ и возрастание удельной массы печени на $19 \%$ ( $<0,05)$, которое обусловлено увеличением количества общих липидов в 3,3 раза (р<0,001) по сравнению с контролем (табл. 2).

В печени визуально отмечалась зернистость жировых включений, что свидетельствует о выраженной жировой инфильтрации, характерной при интоксикации $\mathrm{CCl}_{4}$. Также выявлено повышение активности аланинаминотрансферазы (АлАТ) в плазме крови более чем в 6,6 раза $(\mathrm{p}<0,001)$. Фермент АлАТ является биохимическим маркером печеночных повреждений, а увеличение его активности связано с выходом фермента в кровь в результате повышения проницаемости мембран гепатоцитов.

Одновременно увеличивалась активность цитозольного фермента лизосом $\beta$-галактозидазы в 2,4 раза $(\mathrm{p}<0,001)$ и снижалась активность мембраносвязанного фермента $\beta$-глюкозидазы на $32 \%(\mathrm{p}<0,05)$, что также связано с нарушением структурной организации мембран клеточных органелл и их проницаемости.

Под действием $\mathrm{CCl}_{4}$ в плазме крови повысилось содержание малонового диальдегида (МДА) в 1,8 раза $(\mathrm{p}<0,001)$ по сравнению с контролем, что свидетельствует об активации процессов перекисного окисления липидов (ПОЛ), индуцированного образованием свободных радикалов из $\mathrm{CCl}_{4}$. Образующийся при метаболизме ксенобиотика в системе цитохром Р-450 трихлорметильный радикал, в свою очередь, реагирует с кислородом с образованием еще более токсичного трихлорметилпероксильного радикала [22]. Высокая активность процессов ПОЛ при интоксикации $\mathrm{CCl}_{4}$ свидетельствует о нарушениях в клеточной системе антиоксидантной защиты, выражающихся в снижении уровня восстановленного глутатиона (на 55\%; $\mathrm{p}<0,001)$ и антирадикальной активности (АРА) в крови (на $30 \% ; \mathrm{p}<0,001)$ по отношению к контрольным показателям. Также достоверно ниже контроля (в 2,8 раза) была зафиксирована активность фермента супероксиддисмутазы (СОД), являющегося главным инактиватором супероксид-анион радикала. Такие нарушения в представленных показателях системы антиоксидантной защиты при интоксикации $\mathrm{CCl}_{4}$, можно расценивать как ее истощение.

Таблица 1. Количественный состав нейтральных липидов, фосфолипидов и общих полифенолов в экстракте из жома рябины $(\mathrm{M} \pm \mathrm{m})$

\begin{tabular}{|c|c|}
\hline Показатели & Содержание \\
\hline Общие липиды (мг/мл) & $13,40 \pm 0,14$ \\
\hline Общие полифенолы (мг-экв ГК)/100 мл) & $80,0 \pm 2,50$ \\
\hline АРА (ммоль-экв тролокса/л) & $29,73 \pm 0,23$ \\
\hline Нейтральные липиды (\% от содержания общих липидов) & $89,86 \pm 0,51$ \\
\hline \multicolumn{2}{|c|}{ \% от общего содержания нейтральных липидов } \\
\hline Диацилглицерины & $5,50 \pm 0,42$ \\
\hline Триацилглицерины & $23,10 \pm 1,56$ \\
\hline Свободные жирные кислоты & $13,22 \pm 0,79$ \\
\hline Эфиры жирных кислот & $19,83 \pm 0,81$ \\
\hline Холестерин & $7,75 \pm 0,42$ \\
\hline Эфиры холестерина & $30,85 \pm 1,84$ \\
\hline Фосфолипиды (\% от содержания общих липидов) & $10,14 \pm 0,51$ \\
\hline \multicolumn{2}{|c|}{ \% от общего содержания фосфолипидов } \\
\hline Фосфатидилхолин & $35,50 \pm 1,78$ \\
\hline Фосфатидилэтаноламин & $30,61 \pm 2,07$ \\
\hline Фосфатидилсерин & $33,89 \pm 0,91$ \\
\hline
\end{tabular}

Примечание. АРА - антирадикальная активность, ГК - галловая кислота. 
Таблица 2. Влияние экстракта из жома рябины и препарата «Легалон» на весовые и биохимические

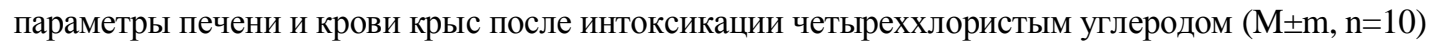

\begin{tabular}{|c|c|c|c|c|c|}
\hline \multirow[t]{2}{*}{ Показатели } & \multicolumn{5}{|c|}{ Группы животных } \\
\hline & $\begin{array}{c}1 \text { 1-я } \\
\text { Контроль }\end{array}$ & $\begin{array}{c}2-я \\
\mathrm{CCl}_{4}\end{array}$ & $\begin{array}{c}\text { 3-я } \\
\text { Депривация }\end{array}$ & $\begin{array}{c}\text { 4-я } \\
\text { Депривация } \\
+ \text { рябина }\end{array}$ & $\begin{array}{c}\text { 5-я } \\
\text { Депривация } \\
\text { + легалон }\end{array}$ \\
\hline Масса животных (г) & $216,0 \pm 2,33$ & $180,8 \pm 2,16^{3}$ & $180,8 \pm 2,90^{3}$ & $220,0 \pm 2,69^{\mathrm{B}}$ & $200,5 \pm 2,79^{3, \mathrm{~B}, \mathrm{e}}$ \\
\hline Удельная масса печени (г/100 г & $4,29 \pm 0,19$ & $5,12 \pm 0,24^{1}$ & $5,79 \pm 0,19^{2}$ & $4,34 \pm 0,09^{\mathrm{B}, д}$ & $4,93 \pm 0,19^{1, \sigma}$ \\
\hline Общие липиды (мг/г ткани) & $43,11 \pm 2,86$ & $140,69 \pm 4,87^{3}$ & $120,46 \pm 4,33^{3}$ & $46,25 \pm 2,37^{\mathrm{B}, \Gamma}$ & $56,16 \pm 3,44^{\mathrm{B}}$ \\
\hline АлАТ (ед/л) & $44,60 \pm 2,17$ & $295,74 \pm 8,65^{3}$ & $140,72 \pm 5,38^{3}$ & $48,70 \pm 2,69^{\mathrm{B}, \mathrm{e}}$ & $63,24 \pm 2,19^{3, \mathrm{в}}$ \\
\hline$\beta$-глюкозидаза (нмоль/мин/г) & $0,19 \pm 0,01$ & $0,13 \pm 0,02^{1}$ & $0,12 \pm 0,01^{3}$ & $0,18 \pm 0,01^{\mathrm{B}}$ & $0,17 \pm 0,01^{6}$ \\
\hline$\beta$-галактозидаза (нмоль/мин/г) & $0,41 \pm 0,03$ & $0,97 \pm 0,08^{3}$ & $0,72 \pm 0,06^{3}$ & $0,46 \pm 0,02^{\mathrm{B}, \mathrm{A}}$ & $0,55 \pm 0,02^{2, \mathrm{a}}$ \\
\hline МДА (нмоль/мл плазмы) & $4,22 \pm 0,16$ & $7,53 \pm 0,40^{3}$ & $9,06 \pm 0,23^{3}$ & $4,52 \pm 0,08^{\mathrm{B}, \mathrm{e}}$ & $5,40 \pm 0,11^{3, \mathrm{~B}}$ \\
\hline АРА (ед. тролокса/ мл плазмы) & $10,93 \pm 0,33$ & $7,68 \pm 0,48^{3}$ & $6,64 \pm 0,20^{3}$ & $10,30 \pm 0,19^{\sigma, \Gamma}$ & $9,50 \pm 0,25^{2,6}$ \\
\hline СОД (усл/ед) & $706,85 \pm 16,96$ & $253,42 \pm 9,50^{3}$ & $211,20 \pm 9,90^{3}$ & $700,97 \pm 9,68^{\mathrm{B}, \mathrm{e}}$ & $590 \pm 12,00^{3, \mathrm{~B}}$ \\
\hline Г-SH (мкмоль/г гемоглобина) & $6,60 \pm 0,17$ & $2,94 \pm 0,08^{3}$ & $3,40 \pm 0,11^{3}$ & $6,98 \pm 0,12^{\mathrm{B}, \mathrm{e}}$ & $6,10 \pm 0,15^{1, \mathrm{~B}}$ \\
\hline
\end{tabular}

Примечание. Различия статистически значимы по сравнению: с контролем: ${ }^{1}-\mathrm{p}<0,05 ;{ }^{2}-\mathrm{p}<0,01 ;{ }^{3}-\mathrm{p}<0,001 ;$ с 3 группой (депривация): ${ }^{\mathrm{a}}-\mathrm{p}<0,05,{ }^{6}-\mathrm{p}<0,01,{ }^{\mathrm{B}}-\mathrm{p}<0,001 ; \mathrm{c} 5$-й группой (легалон): ${ }^{\mathrm{r}}-\mathrm{p}<0,05,{ }^{\not}-\mathrm{p}<0,01,{ }^{\mathrm{e}}-\mathrm{p}<0,001$. АлАт аланинаминотрансфераза, МДА - малоновый диальдегид, АРА - антирадикальная активность, СОД - супероксиддисмутаза, Г-SH - восстановленный глутатион.

Через 7 дней после отмены $\mathrm{CCl}_{4}$ (3-я группа, период депривации) весовые характеристики и большинство изученных биохимических параметров к норме не возвратилось. В печени отмечалась зернистость жировых включений, то есть сохранялась жировая инфильтрация, характерная при токсическом гепатите. Количество общих липидов печени превышало контрольный уровень в 2,8 раза (p<0,001). Проницаемость мембран гепатоцитов также не восстановилась в период депривации, о чем свидетельствует повышенная активность АлАТ в плазме крови в 3 раза по отношению к контролю. Следует отметить факт еще большего снижения активности мембраносвязанной $\beta$-глюкозидазы и сохранения повышенной активности $\beta$-галактозидазы по сравнению с контролем, что свидетельствует о нарушении структурной целостности лизосомальных мембран и их проницаемости. В период депривации также сохранялось рассогласование ферментов антиоксидантной защиты. Так, активность СОД оставалась на уровне показателей 2-й группы (в 3 раза ниже контрольного уровня). Пул восстановленного глутатиона относительно 2-й группы (интоксикация $\mathrm{CCl}_{4}$ ) несколько увеличился, но относительно контроля сохранялся достоверно пониженным (на $48 \%, \mathrm{p}<0,001)$. Также отмечалась высокая величина МДА (в 2,2 раза выше контроля; р<0,001), которая превышала таковую во 2-й группе на $18 \%$ ( $<0,001)$. Все эти факторы являются результатом низкого антиоксидантного и антирадикального статуса организма в период депривации, в пользу чего свидетельствует еще большее снижение АРА (на 39\%; р<0,001) в плазме крови по сравнению с контрольными величинами. Таким образом, отмена токсиканта в течение 7 дней сопровождается неполным восстановлением функционального состояния печени крыс. По нашему мнению, период отмены токсического агента является стрессом для организма, так как стали еще выше различия с контролем и со 2-й группой для некоторых изученных биохимических показателей, а также удельной массы печени.

При введении животным экстракта из жома рябины (4-я группа) в период отмены $\mathrm{CCI}_{4}$ отмечалась нормализация весовых характеристик животных, удельной массы печени, а также содержания общих липидов в ткани печени. В то же время при введении препарата сравнения «Легалон ${ }^{\circledR} »(5-я$ группа) была выражена лишь тенденция к их нормализации. Так, масса тела у животных 5-й группы была достоверно ниже контроля на $8 \%$ ( $<0,05)$, при этом удельная масса печени и содержание общих липидов превышали контроль на 15 и $30 \%$ ( $<<0,05)$ соответственно.

В отношении биохимических показателей у животных 4-й группы, получавших экстракт рябины, отмечалось восстановление активности АлАТ в сыворотке крови и лизосомальных гидролаз в печени, что свидетельствует о мембраностабилизирующих свойствах экстракта. В то же время у животных 5-й группы, получавших легалон, активности АлАТ и $\beta$-галактозидазы были выше контрольного уровня на $42 \%$ $(\mathrm{p}<0,001)$ и $34 \%$ ( $<<0,01)$, что указывает на сохраняющуюся повышенную проницаемость мембран гепатоцитов и лизосом. При этом активность мембраносвязанного фермента $\beta$-глюкозидазы существенно возросла до уровня контроля в обеих группах. Можно предположить, что фосфолипиды, входящие в состав экс- 
тракта, обусловливают его репаративное действие в отношении клеточных мембран, о чем свидетельствует снижение активности АлАТ и восстановление активности лизосомальных ферментов.

Исследование величин антирадикальной и антиоксидантной систем защиты при введении растительных препаратов (4-я и 5-я группы) выявило достоверное увеличение активности COД, величины APA, Г-SH и снижение уровня МДА по сравнению с соответствующими показателями в 3-й группе (депривация). Повидимому, антиоксидантную и антирадикальную функцию выполняли полифенолы, входящие в состав растительных препаратов, как физиологически совместимые антиоксиданты [23] и «ловушки» свободных радикалов. Однако при введении легалона уровни Г-SH, APA и активность СОД оставались достоверно ниже контроля (в среднем на 8-16\%), а содержание МДА превышало его значения на 28\% (p<0,001).

Таким образом, введение экстракта из жома рябины и легалона сопровождалось более эффективным восстановлением изученных показателей печени, чем в период обычной депривации без применения растительных комплексов. Действие экстракта из жома рябины в восстановлении антиоксидантной защиты печени не уступает эталонному препарату сравнения легалон в отношении исследуемых параметров. Известно, что в состав легалона входит активная группа изомерных флавоноидных соединений (силибинин, силикристин, силидианин), не образующих олигомерных форм [24]. Экстракт из жома рябины, содержащий в своем составе многокомпонентный полифенольный комплекс, демонстрирует антиоксидантные свойства в равной степени, что и изомерные флавоноиды легалона.

\section{Bbыводbl}

1. В составе экстракта, выделенного из сухого жома рябины, выявлено наличие полифенольного и липидного комплекса. Содержание общих полифенолов составляло $80 \pm 2,5$ мг-экв ГК на 100 мл, что обусловливает высокую антирадикальную активность экстракта. Липидная составляющая экстракта включала фосфолипиды и нейтральные липиды, их содержание находилось в пределах 13,4 \pm 0,14 мг общих липидов/мл.

2. Экстракт из жома рябины проявлял выраженные антиоксидантные и мебранопротекторные свойства при внутрижелудочном введении крысам с экспериментальным $\mathrm{CCl}_{4}-$ гепатитом. По параметрам антиоксидантной активности экстракт не уступал препарату сравнения легалон.

3. Экстракт из жома рябины является перспективным источником для создания биологически активных добавок с высокой антиоксидантной и антирадикальной активностью и их рационального использования в функциональных продуктах.

\section{Список литературы}

1. Тихонов В.Н., Калинкина Г.И., Сальникова Е.Н. Лекарственные растения, сырье и фитопрепараты: учебное пособие / под ред. проф. С.Е. Дмитрука. Часть І. Томск, 2004. 116 с.

2. Государственная фармакопея СССР. ХІ издание. Вып. 2. Общие методы анализа. Лекарственное растительное сырье. М., 1990. 385 с.

3. Петрова C.Н., Ивкова А.В. Химический состав и антиоксидантные свойства видов Rosa L. // Химия растительного сырья. 2014. №2. С. 13-19.

4. Спрыгин В.Г., Кушнерова Н.Ф., Фоменко С.Е. Отходы от переработки дальневосточных дикоросов - перспективные источники пищевых антиоксидантов // Известия Самарского научного центра РАН. 2010. Т. 12, №1(3). C. 812-815.

5. Olszewska M.A., Michel P. Antioxidant activity of inflorescences, leaves and fruits of three Sorbus species in relation to their polyphenolic composition // Natural Product Research. 2009. Vol. 23. N16. Pp. 1507-1521.

6. Kylli P., Nohynek L., Puupponen-Pimiä R., Westerlund-Wikström B., McDougall G., Stewart D., Heinonen M. Rowanberry phenolics: compositional analysis and bioactivities // J. Agricultural and Food Chemistry. 2010. Vol. 58. N22. Pp. 11985-11992.

7. Hukkanen A.T., Pölönen S.S., Kärenlampi S.O., Kokko H.I. Antioxidant capacity and phenolic content of sweet rowanberries // J. Agricultural and Food Chemistry. 2006. Vol. 54. N1. Pp. 112-119.

8. Nakatani N. Antioxidants from spices and herbs // Natural antioxidants chemistry, health effects and applications. Champaign, Illinois: AOCS Press, 1996. Pp. 65-75.

9. Дикорастущие полезные растения России / отв. ред. А.Л. Буданцев, Е.Е. Лесиовская. СПб., 2001. 663 с.

10. Singleton V.L., Orthofer R., Lamuela-Raventos R.M. Analysis of total phenols and other oxidation substrates and antioxidants by means of Folin-ciocalteu reagent // Oxidants and Antioxidants. San Diego: Academic Press Inc., 1999. Vol. 299. Pp. 152-178. 
11. Re R., Pellegrini N., Proteggente A., Pannala A., Yang M., Rice-Evans C.A. Antioxidant activity applying an improved $\mathrm{ABTS}^{+}$radical cation decolorization assay // Free Radical Biology \& Medicine. 1999. Vol. 26. N9-10. Pp. 1231-1237.

12. Folch J., Less M., Sloane Stanley G.H. A simple methods for the isolation and purification of total lipids from animal tissues // J. Biological Chemistry. 1957. Vol. 226. Pp. 497-509.

13. Svetashev V.I., Vaskovsky V.E. Asimplified technique for thinlayer microchromatography of lipids // J. Chromatography. 1972. Vol. 67. N2. Pp. 376-378.

14. Vaskovsky V.E., Kostetsky E.Y., Vasenden I.M. A universal reagent for phospholipid analysis // J. Chromatography. 1975. Vol. 114. N1. Pp. 129-141.

15. Amenta J.S. A rapid chemical method for quantification of lipids separated by thin-layer chromatography // J. Lipid Res. 1964. Vol. 5. N2. Pp. 270-272.

16. Руководство по экспериментальному (доклиническому) изучению новых фармакологических веществ / под ред. Р.У. Хабриева. Москва, 2005. 832 с.

17. Венгеровский А.И., Маркова И.В., Саратиков А.С. Доклиническое изучение гепатозащитных средств // Ведомости фарм. комитета. 1999. №2. С. 9-12.

18. Paoletti F., Aldinucci D., Mocali A., Caparrini A. A sensitive spectrophotometric method for the determination of superoxide dismutase activity in tissue extracts // Analytical biochemistry. 1986. Vol. 154. N2. Pp. 536-541.

19. Новгородцева Т.П., Эндакова Э.А., Янькова В.И. Руководство по методам исследования параметров системы «Перекисное окисление липидов - антиоксидантная защита» в биологических жидкостях. Владивосток, 2003. $80 \mathrm{c}$.

20. Buege J.A., Aust S.D. Microsomal lipid peroxidation // Methods in Enzymology. 1978. Vol. 52. Pp. 302-310.

21. Меркурьева Р.В., Билич Г.Л., Нарциссов Р.П. Биохимические и цитохимические методы определения активности ферментов и фермент-субстратных систем различной клеточной локализации. М., 1982.40 с.

22. Weber L.M., Boll M., Stampfl A. Hepatotoxicity and mechanism of action of haloalkanes: carbon tetrachloride as a toxicological model // Critical Reviews in Toxicology. 2003. Vol. 33. N2. Pp. 105-136.

23. Новиков В.Е., Левченкова О.С. Новые направления поиска лекарственных средств с антигипоксической активностью и мишени для их действия // Экспериментальная и клиническая фармакология. 2013. Т. 76 . №5. C. 37-47.

24. Ding T., Tian S., Zhang Z., Gu D., Chen Y., Shi Y., Sun Z. Determination of active component in silymarin by RPLC and LC/MS // J. Pharmaceutical and Biomedical Analysis. 2001. Vol. 26, N1. Pp. 155-161.

Поступило в редакиию 3 февраля 2015 г.

После переработки 16 апреля 2015 г.

\author{
Fomenko S.E. ${ }^{1}$, Kushnerova N.F. ${ }^{l}$, Sprygin V.G. ${ }^{1}$, Drugova E.S. ${ }^{l}$, Momot T.V. ${ }^{2}$ CHEMICAL COMPOSITION AND \\ BIOLOGICAL ACTIVITY OF THE ROWANBERRY EXTRACT \\ ${ }^{I}$ V.I. Il'ichev Pacific Oceanological Institute FEBRAS, ul. Baltijskaya, 43, Vladivostok, 690041 (Russia), \\ e-mail: sfomenko@poi.dvo.ru. \\ ${ }^{2}$ Biomedicine school of Far Eastern Federal University, ul. Sukhanova, 8, Vladivostok, 690950 (Russia)
}

The object of this study was the extract obtained from the dried pomace of rowanberry amurensis (Sorbus amurensis Koehne) after juice separation. It was studied the total polyphenols contents, lipids pattern and antiradical activity of the extract. The total polyphenols contents made $80 \pm 2,5 \mathrm{mg}$ gallic acid equivalents per $100 \mathrm{ml}$, which specify the level of its antiradical activity that was determined at the level of $29,73 \pm 0,23$ mmol equvalents of trolox per liter. Lipids constituent included 3 phospholipid and 6 neutral lipids fractions. Its contents was found within 13,4 $\pm 0,14 \mathrm{mg}$ of total lipids per ml. Findings indicate to the high biological activity of the extract and the reasonability of its experimental study. It was shown on the laboratory model of toxic carbon tetrachloride hepatitis in rats that extract from the rowanberry at endogastric administration in dosage of $100 \mathrm{mg}$ of total polyphenols per $\mathrm{kg}$ of body weight, possess expressed antioxidant and hepatoprotective activity. Administration of the extract facilitate the decreasing of the general lipids contents, specific liver weight, alanine aminotransferase activity, as well the level of the reduced glutathione and activity antioxidant and lysosomal enzymes is normalized. Extract from rowanberry is a promising source for developing of biologically active food supplements with high antioxidant and antiradical activity.

Keywords: extract of rowanberry, total polyphenols, lipids, antiradical and antioxidant activity, toxic hepatitis.

\footnotetext{
* Corresponding author.
} 


\section{References}

1. Tihonov V.N., Kalinkina G.I., Sal'nikova E.H. Lekarstvennye rastenija, syr'e i fitopreparaty: uchebnoe posobie [Medicinal plants and herbal materials: Textbook], ed. prof. S.E. Dmitruk, part I, Tomsk, 2004, 116 p. (in Russ.).

2. Gosudarstvennaja farmakopeja SSSR. XI izdanie. Vyp. 2. Obshhie metody analiza. Lekarstvennoe rastitel'noe syr'e. [The State pharmacopoeia of the USSR. XI Ed. Vol. 2. General methods of analysis. Medicinal herbs]. Moscow, 1990, 385 p. (in Russ.).

3. Petrova S.N., Ivkova A.V. Himija rastitel'nogo syr'ja, 2014, no. 2, pp. 13-19. (in Russ.).

4. Sprygin V.G., Kushnerova N.F., Fomenko S.E. Izvestija Samarskogo nauchnogo centra RAN, 2010, vol. 12, no. 1(3), pp. 812-815. (in Russ.).

5. Olszewska M.A., Michel P. Natural Product Research, 2009, vol. 23, no. 16, pp. 1507-1521.

6. Kylli P., Nohynek L., Puupponen-Pimiä R., Westerlund-Wikström B., McDougall G., Stewart D., Heinonen M. J. Agricultural and Food Chemistry, 2010, vol. 58, no. 22, pp. 11985-11992.

7. Hukkanen A.T., Pölönen S.S., Kärenlampi S.O., Kokko H.I. J. Agricultural and Food Chemistry, 2006, vol. 54, no. 1, pp. 112-119.

8. Nakatani N. Natural antioxidants chemistry, health effects and applications. Champaign, Illinois: AOCS Press, 1996, pp. 65-75.

9. Dikorastushhie poleznye rastenija Rossii [Wild useful plants Russia] ed. A.L. Budancev, E.E. Lesiovskaja. Saint Petersburg, 2001, 663 p. (in Russ.).

10. Singleton V.L., Orthofer R., Lamuela-Raventos R.M. Oxidants and Antioxidants, San Diego: Academic Press Inc, 1999, vol. 299, pp. 152-178.

11. Re R., Pellegrini N., Proteggente A., Pannala A., Yang M., Rice-Evans C.A. Free Radical Biology \& Medicine, 1999, vol. 26, no. 9-10, pp. 1231-1237.

12. Folch J., Less M., Sloane Stanley G.H. J. Biological Chemistry, 1957, vol. 226, pp. 497-509.

13. Svetashev V.I., Vaskovsky V.E. J. Chromatography, 1972, vol. 67, no. 2, pp. 376-378.

14. Vaskovsky V.E., Kostetsky E.Y., Vasenden I.M. J. Chromatography, 1975, vol. 114, no. 1, pp. 129-141.

15. Amenta J.S. J. Lipid Res. 1964, vol. 5, no. 2, pp. 270-272.

16. Rukovodstvo po jeksperimental'nomu (doklinicheskomu) izucheniju novyh farmakologicheskih veshhestv [Manual on experimental (preclinical) study of new pharmacological substances] ed. R.U. Habriev. Moscow, 2005, 832 p. (in Russ.).

17. Vengerovskij A.I., Markova I.V., Saratikov A.S. Vedomosti farm. komiteta. 1999, no. 2, pp. 9-12. (in Russ.).

18. Paoletti F., Aldinucci D., Mocali A., Caparrini A. Analytical biochemistry, 1986, vol. 154, no. 2, pp. 536-541.

19. Novgorodceva T.P., Jendakova Je.A., Jan'kova V.I. Rukovodstvo po metodam issledovanija parametrov sistemy "Perekisnoe okislenie lipidov - antioksidantnaja zashhita" v biologicheskih zhidkostjah. [Manual methods of investigation system parameters "Lipid peroxidation - antioxidant protection" in the biological fluids]. Vladivostok, 2003, 80 p. (in Russ.).

20. Buege J.A., Aust S.D. Methods in Enzymology, 1978, vol. 52, pp. 302-310.

21. Merkur'eva R.V., Bilich G.L., Narcissov R.P. Biohimicheskie i citohimicheskie metody opredelenija aktivnosti fermentov $i$ ferment-substratnyh sistem razlichnoj kletochnoj lokalizacii. [Biochemical and cytological methods for determining the activity of enzymes and enzyme-substrate systems of different cellular localization]. Moscow, 1982. 40 p. (in Russ.).

22. Weber L.M., Boll M., Stampfl A. Critical Reviews in Toxicology, 2003, vol. 33, no. 2, pp. 105-136.

23. Novikov V.E., Levchenkova O.S. Jeksperimental'naja i klinicheskaja farmakologija, 2013, vol. 76, no. 5, pp. 37-47. (in Russ.).

24. Ding T., Tian S., Zhang Z., Gu D., Chen Y., Shi Y., Sun Z. J. Pharmaceutical and Biomedical Analysis, 2001, vol. 26, no. 1, pp. 155-161. 